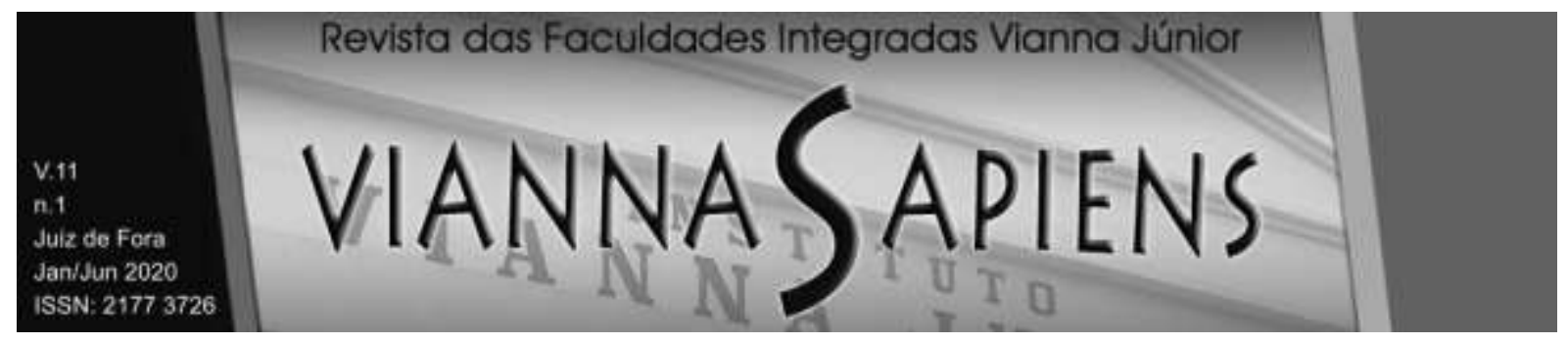

\title{
O üntermassverbot do direito alemão e a extinção da punibilidade pelo pagamento do tributo no direito penal tributário \\ DOI: 10.31994/rvs.v11i1.668
}

\author{
Jéssica Cavalcanti Barros Ribeiro ${ }^{1}$
}

\section{RESUMO}

O objetivo do artigo é analisar o "Princípio da Proporcionalidade" no Direito Penal, sobretudo na sua acepção de vedação à proteção deficiente (üntermassverbot) do Estado, frente à extinção da punibilidade pelo pagamento do tributo nos crimes contra a ordem tributária. Trata-se de uma pesquisa descritiva, cuja metodologia empregada foi uma pesquisa bibliográfica, utilizando-se também de análise jurisprudencial. Ao final, conclui-se que o Estado utiliza incorretamente o Direito Penal Tributário como simples instrumento de cobrança de dívidas fiscais, evidenciando uma total proteção deficiente (üntermassverbot) da norma penal tributária.

PALAVRAS-CHAVE: EXTINÇÃO DA PUNIBILIDADE. PAGAMENTO. TRIBUTO.

\footnotetext{
${ }^{1}$ Especialista em Direito Constitucional pela Universidade Cândido Mendes, especialista em Direito Penal pela Faculdade Damásio de Jesus, especialista em Direito Tributário pela Faculdade Única. Bacharela em Direito pela Universidade do Estado da Bahia (UNEB). Professora de Direito Penal e Direito Constitucional da Autarquia Educacional do Vale do São Francisco - AEVSF, advogada. ORCID: <https://orcid.org/0000-0002-6243-2824>
} 


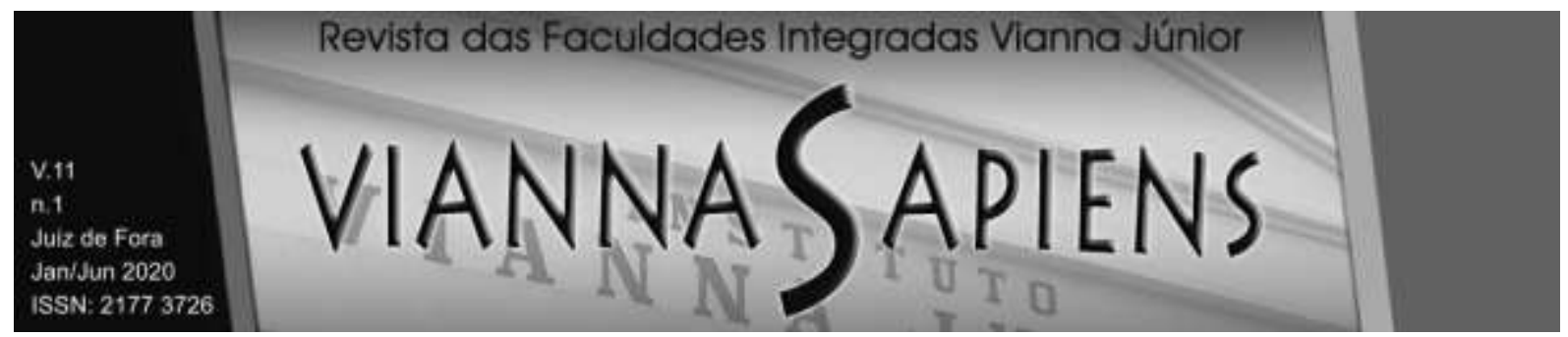

The üntermassverbot of german law and the extinction of punibility by paying the tax in tributary criminal law

\begin{abstract}
The objective of the article is to analyze the Principle of Proportionality in Criminal Law, especially in its sense of prohibition against deficient protection (üntermassverbot) of the State, in view of the extinction of punishment for the payment of tax in crimes against the tax order. It is a descriptive research, whose methodology used was a bibliographic research, also using jurisprudential analysis. In the end, it is concluded that the State incorrectly uses Criminal Tax Law as a simple instrument for collecting tax debts, showing total deficient protection (üntermassverbot) of the tax penal rule.
\end{abstract}

\title{
KEYWORDS: EXTINCTION OF PUNISHMENT. PAYMENT. TRIBUTE
}

\section{INTRODUÇÃO}

Sabemos que, no Brasil, o processo por crimes contra a Ordem Tributária acaba por não punir adequadamente o reú, sobretudo porque o pagamento da dívida extingue a punibilidade, afrontando o Princípio da Proporcionalidade. Na verdade, utiliza-se o Direito Penal como mero instrumento para se cobrar tributos, e não para se punir o infrator da lei.

O presente trabalho, assim, pretende investigar o Princípio da Proporcionalidade, mais precisamente, a vedação da proteção deficiente por parte do Estado, e sua aplicação no ramo do Direito Penal Tributário, em relção à extinção da punibilidade pelo pagamento do tributo devido pelo contribuinte. $O$ estudo se baseia em pesquisa bibliográfica, utilizando, como fontes, artigos, livros, jurisprudência, trabalhos e artigos acadêmicos. É trazido como problematização se 


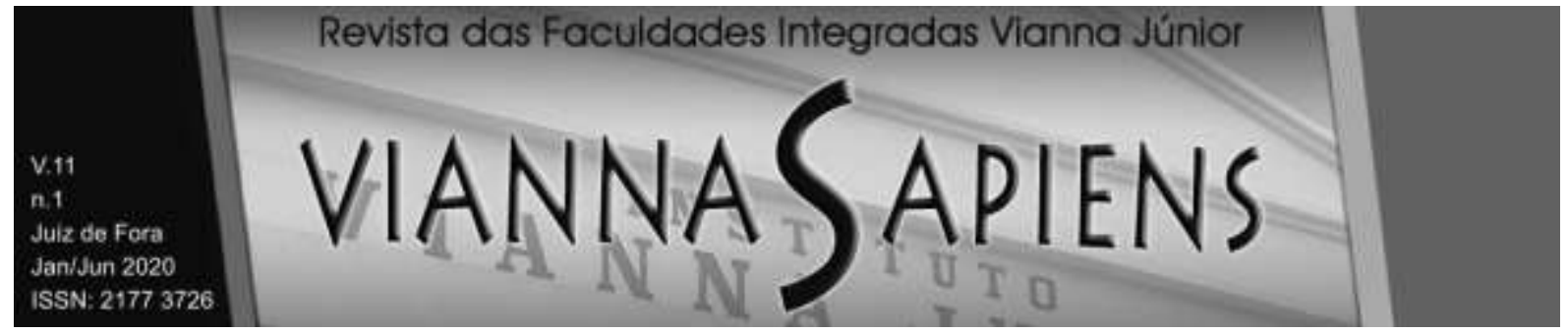

a extinção da punibilidade pelo pagamento do tributo, nos crimes contra a Ordem Tributária, ofende o Princípio da Proporcionalidade, tendo-se como hipótese a ser testada que a utilização do Direito Penal como mero cobrador de tributos ofende o Princípio da Proporcionalidade.

Inicialmente, no primeiro tópico, analisa-se o Princípio da Proporcionalidade, que se subdivide em duas acepções: proibição do excesso (Übermassverbot) e proibição de proteção deficiente (Üntermassverbot). Sendo o Direito Penal o mais violento mecanismo de controle social, ele não pode ser absoluto na aplicação de sua violência, por outro lado, ele também não pode ser demais brando, pois resultará em impunidade. É por isso que o Direito Penal é regido por princípios, sobretudo os princípios em questão.

Desenvolvendo o tema, o segundo tópico trata da vedação à proteção deficiente da norma penal tributária por parte do Estado e da utilização do Direito Penal como instrumento de cobraça de dívidas fiscais. A partir do momento em que o legislador relativiza o bem jurídico "Ordem Tributária", permitindo a extinção da punibilidade com o mero pagamento da dívida, tem-se o desrespeito ao Princípio da Proporcionalidade. Consequentemente, reduz-se todo um sistema jurídico penal a um mero cobrador de dívidas.

Por fim, no terceiro tópico, há a comparação entre o abrandamento da punição nos delitos contra o patrimônio e os delitos contra a ordem tributária, em relação à reparação do dano e ao pagamento devido.

\section{A PROIBIÇÃO DO EXCESSO (ÜBERMASSVERBOT) E A PROIBIÇÃO DA PROTEÇÃO DEFICIENTE (ÜNTERMASSVERBOT) COMO ACEPÇÕES DO PRINCÍPIO DA PROPORCIONALIDADE}

No Direito Penal, a Proporcionalidade é princípio implícito, desdobramento lógico do mandamento da individualização da pena, que está previsto no art. $5^{\circ}$, XLVI da Constituição Federal. Este desdobramento ocorre porque, segundo este princípio, 


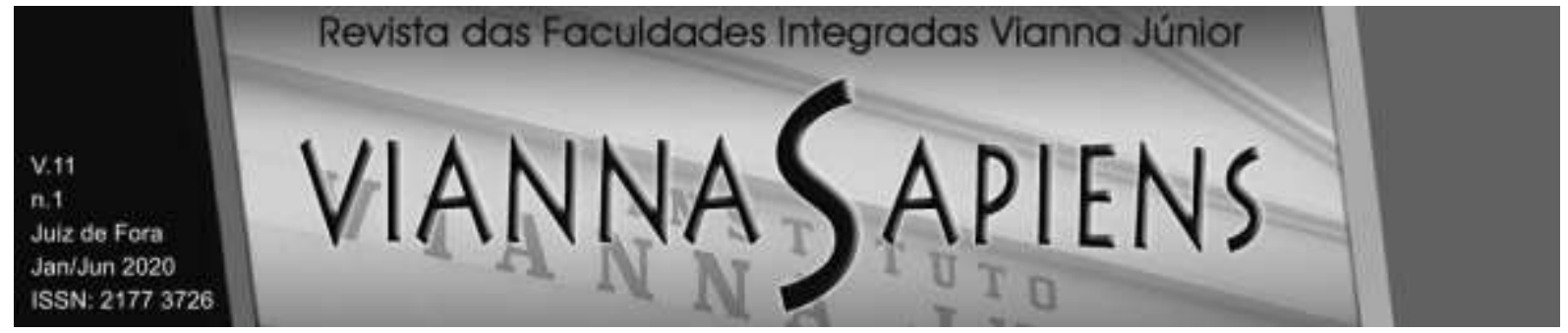

deve-se atribuir a cada indivíduo o que lhe cabe, de acordo com as consequências de seu comportamento. A criação de tipos penais incriminadores deve se constituir em atividade vantajosa para os membros da sociedade, pois impõe um ônus a todos os cidadãos, decorrente da ameaça de punição que a eles acarreta (MASSON, 2019).

O Princípio da Proporcionalidade se divide em 1) proibição do excesso (Übermassverbot) e 2) proibição de proteção deficiente (Üntermassverbot). Tais conceitos tiveram sua gênese no Direito Alemão, sob a inspiração de pensamentos jusnaturalistas e iluministas, com os quais se afirmam as ideias de que a limitação da liberdade individual só se justifica para a concretização de interesses coletivos superiores. A proibição do excesso (Übermassverbot) visa a frear o poder punitivo do Estado, tratando-se de um modelo normativo que obedece à estrita legalidade $e$ é voltado a minimizar a violência e maximizar a liberdade, impondo limites à função punitiva do Estado (Dias, 2017). Nesse sentido, veda-se a cominação e aplicação de penas em dose exagerada e desnecessária. Por sua vez, a proibição de proteção deficiente (Üntermassverbot) é o revés da proibição do excesso, quando o Estado não legisla acerca de um determinado direito fundamental, desprotegendo-o, e não evita a impunidade. Também é desproporcial a imposição de sanção abaixo da medida correta. 7

Na diccção de Queiroz (2006), se por um lado deve ser combatida a sanção desproporcional porque excessiva, por outro lado há a necessidade de evitar a resposta penal que fique muito aquém do seu efetivo merecimento, afinal a desproporção tanto pode dar-se para mais, quanto para menos.

\section{A UTILIZAÇÃO DO DIREITO PENAL COMO MECANISMO DE COBRANÇA DE DÍVIDAS TRIBUTÁRIAS: A VERDADEIRA PROTEÇÃO DEFICIENTE (UNTERMASSVERBOT)}

Infrações à legislação tributária acarretam, via de regra, sanções administrativas. Contudo, o legislador criminaliza determinadas condutas que 


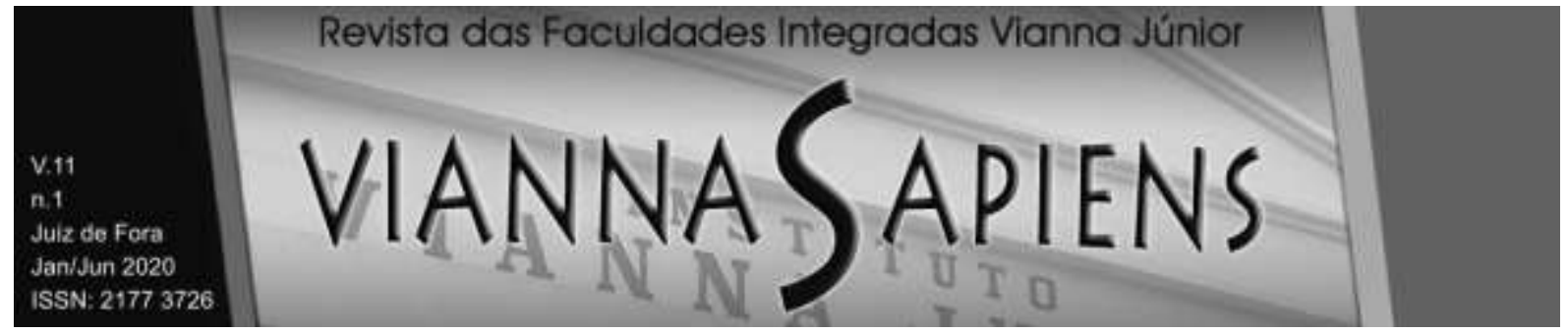

apresentam maior caráter ofensivo, punindo-se, inclusive, com penas privativas de liberdade, a exemplo das condutas previstas nos artigos $1^{\circ}$ e $2^{\circ}$ da Lei 8137/90, no art. 168-A, do Código Penal (apropriação indébita previdenciária), e no art. 337-A do Código Penal (sonegação de contribuição previdenciária).

Em que pese o legislador ter escolhido punir, com pena privativa de liberdade, condutas que ofendem a legislação tributária, o art. 9ำ, § 2ํ, da Lei ํo 10.684/2003 permite a extinção da punibilidade a qualquer tempo, dos crimes contra a ordem tributária, desde que realizado o pagamento total da dívida. Assim, os crimes contra a Ordem Tributária previstos no art. $1^{\circ}$ e $2^{\circ}$ da Lei 8137/90, a apropriação indébita previdenciária (art. 168-A CP) e sonegação de contribuição previdenciária (art. 337A CP) tem a punibilidade extinta através do pagamento integral do crédito. $O$ Supremo Tribunal Federal e o Superior Tribunal de Justiça corroboram esse entendimento, emitindo-o em diversos julgados, vejamos:

O pagamento integral do débito tributário, a qualquer tempo, até mesmo após o trânsito em julgado da condenação, é causa de extinção da punibilidade do agente, nos termos do art. 9으 $\S 2^{\circ}$, da Lei no 10.684/2003. (STJ. 5a Turma.HC 362478-SP, Rel. Min. Jorge Mussi, julgado em 14/9/2017 Info 611).

O pagamento integral do débito tributário, a qualquer tempo, até mesmo após o trânsito em julgado da condenação, é causa de extinção da punibilidade do agente, nos termos do art. $9^{\circ}, \S 2^{\circ}$, da Lei no 10.684/2003. (STF. 2 ${ }^{\text {a }}$ Turma. RHC 128245, Rel. Min. Dias Toffoli, julgado em 23/08/2016)

É notável que, ao contrário da maioria dos crimes, não se analisa nenhum critério subjetivo, como o dolo ou a culpa. Assim, nos crimes contra a Ordem Tributária, não se faz nenhuma análise subjetiva da conduta do agente de se esquivar do pagamento, basta que se pague integralmente o débito para que seja determinada a extinção da punibilidade.

O Direito Penal Tributário é a ramificação específica do Direito Penal, tratando dos crimes contra a ordem tributária. Como ramo do Direito Penal, sujeita-se a todas as regras e princípios deste, e deveria se sujeitar também à análise dos elementos 


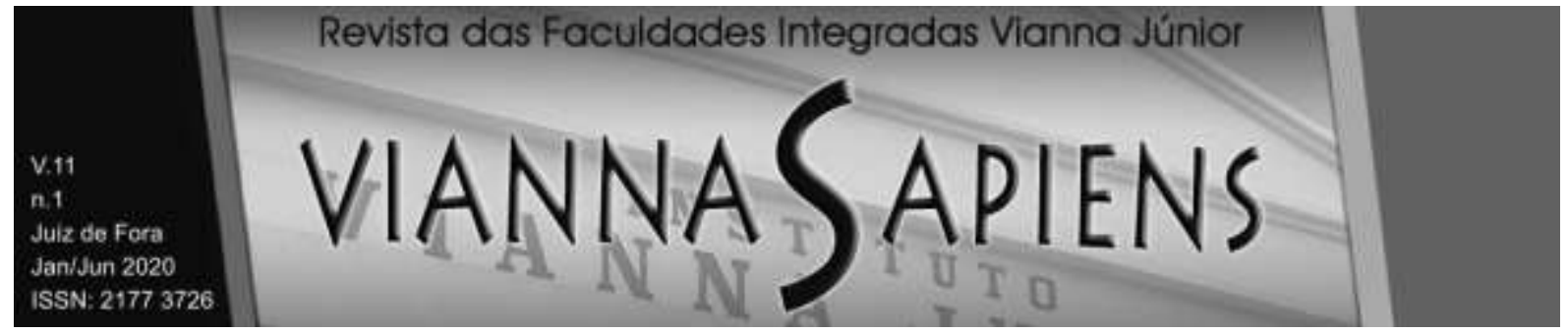

subjetivos (dolo e culpa). Sobre a questão, pondera Baltazar Júnior (2017, p. 796) que:

Esse conjunto forma o chamado direito penal tributário, ou seja, o conjunto de normas de natureza penal que sancionam práticas relacionadas à violação de natureza tributária, que não deve ser confundido com o direito tributário penal, cujo objeto são as sanções de ordem administrativo-tributária.

Pode-se afirmar que, em que pese algumas particularidades, ontologicamente o delito penal tributário não se diferencia do delito penal comum. O Direito Penal Tributário é, portanto, o conjunto de normas que regulam os delitos tributários e as respectivas sanções, sendo certo que o adjetivo "tributário" pretende apenas dizer que as normas penais, que fazem parte da disciplina matriz, colocam sob sua tutela matéria tributária (PINTO, 2001).

Como são aplicadas normas do Direito Penal aos crimes tributários, aplicamse também os princípios próprios do Direito Penal, o que acaba por afrontar o Princípio da Intervenção Mínima e da Proporcionalidade, eis que se criminaliza uma conduta que poderia ser suficientemente punida pelo próprio Direito Tributário, através de suas multas e demais mecanismos de repreensão. Isso reitera o caráter seletivo do Direito Penal, tornando-o instrumento que pune os menos favorecidos e beneficia as elites (praticantes da criminalidade econômico-financeira). Pode-se verificar que o interesse do fisco, quando da criminalização da sonegação fiscal, reside na coerção do contribuinte ao pagamento do crédito tributário, e apenas isso. Confere-se, desta maneira, um efeito simbólico à pena.

Salienta-se que existe uma real dificuldade em se punir quem pratica crimes desse jaez, uma vez que, com o pagamento, extingue-se a punibilidade. Ora, se a conduta do indivíduo é tão grave que merece tipificação penal, não há motivos para estabelecer uma norma despenalizante sem qualquer critério subjetivo de avaliação, o que viola os princípios do Direito Penal. Essa questão, em verdade, deveria ser objeto apenas do Direito Tributário.

De acordo com a Portaria № 75/12, do Ministério da Fazenda, foi determinado 


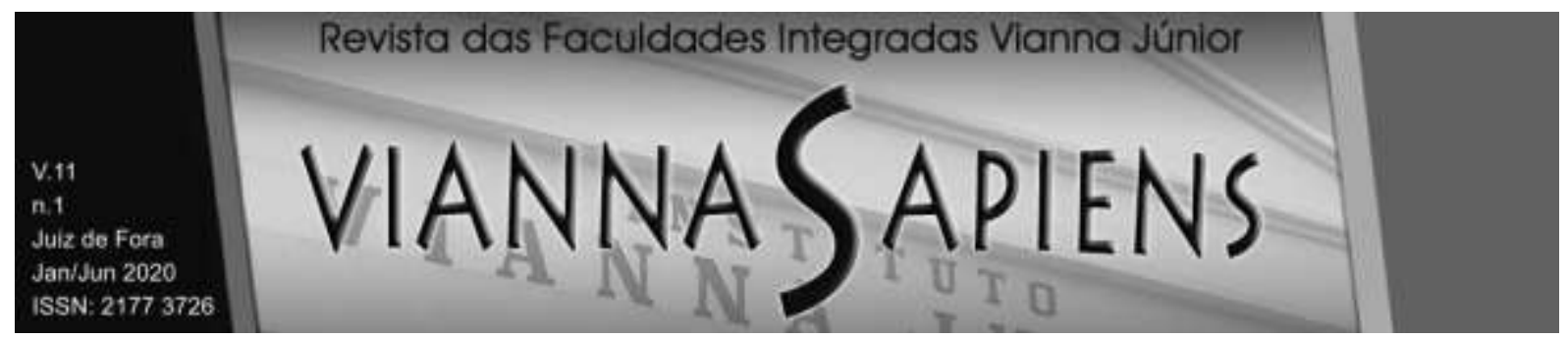

que não fossem ajuizadas execuções fiscais com valores abaixo de $R \$ 20.000,00$ (vinte mil reais). Diante dessa Portaria, defende-se a tese de que o novo parâmetro para análise da insignificância penal nos crimes tributários passou de 10 mil reais (de acordo com o art. 20 da Lei $n^{\circ}$ 10.522/2002) para 20 mil reais (com base na Portaria Ministério da Fazenda ํㅜㄱㅏ). Atualmente, o Supremo Tribunal Federal e Superior Tribunal de Justiça declararam com válida esta mudança:

HABEAS CORPUS. DIREITO PENAL. DESCAMINHO. VALOR INFERIOR AO ESTIPULADO PELO ART. 20 DA LEI 10.522/2002. PORTARIAS 75 E 130/2012 DO MINISTÉRIO DA FAZENDA. PRINCÍPIO DA INSIGNIFICÂNCIA. APLICABILIDADE. ORDEM CONCEDIDA.

1. A pertinência do princípio da insignificância deve ser avaliada considerando-se todos os aspectos relevantes da conduta imputada. 2. Para crimes de descaminho, considera-se, para a avaliação da insignificância, o patamar de $R \$ 20.000,00$, previsto no art 20 da Lei n.- 10.522/2002, atualizado pelas Portarias 75 e 130/2012 do Ministério da Fazenda. Precedentes.

3. Na espécie, aplica-se o princípio da insignificância, pois o descaminho envolveu elisão de tributos federais que perfazem quantia inferior ao previsto no referido diploma legal.

4. Ordem concedida.

(STF - Acórdão Hc 120617 / Pr - Paraná, Relator(a): Min. Rosa Weber, data de julgamento: 04/02/2014, data de publicação: 20/02/2014, $1^{\text {a }}$ Turma)

Incide o princípio da insignificância aos crimes tributários federais e de descaminho quando o débito tributário verificado não ultrapassar o limite de $R \$ 20.000,00$ (vinte mil reais), a teor do disposto no art. 20 da Lei n. 10.522/2002, com as atualizações efetivadas pelas Portarias n. 75 e 130, ambas do Ministério da Fazenda. STJ. $3^{a}$ Seção. REsp 1.709.029/MG, Rel. Min. Sebastião Reis Júnior, julgado em 28/02/2018 (recurso repetitivo).

Desse modo, com o estabelecimento deste patamar mínimo, considera-se insignificante tudo o que estiver abaixo do valor de $\mathrm{R} \$ 20.000,00$ (vinte mil reais). Percebe-se assim que há uma incoerência no Ordenamento Jurídico, pois, por exemplo, alguém que deixa de pagar tributo no montante de $\mathrm{R} \$ 1.000,00$ pode ter a sua pena extinta caso quite a dívida, enquanto que uma pessoa que furta um celular no valor de $\mathrm{R} \$ 1.000,00$ não terá sua pena extinta caso devolva ou pague o dano. $\mathrm{O}$ doutrinador Streck (2015) entende que: 


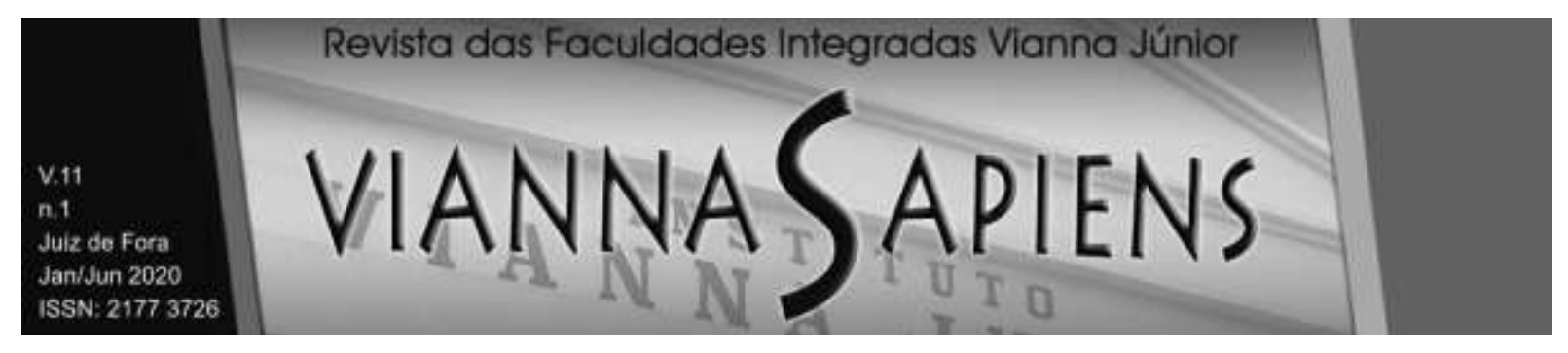

Qual é o recado que o Estado (lato sensu) dá? Tributos até $\mathrm{R} \$ 20$ mil não vale a pena pagar, por duas razões: a uma, o governo não cobrará, porque não vale a pena; a duas, porque, se não vale a pena cobrar, também não vale a pena processar criminalmente; é o que se chama "insignificância diferida" ou "insignificância por efeito colateral". Uma pergunta: está sobrando dinheiro no governo federal? Os procuradores que tratam disso não se insurgem? Lembro a todos que no Brasil tem uma coisa - que pode até não ter importância que se chama Constituição. E tem outra coisa chamada "controle difuso". E mais ainda: ninguém é obrigado a cumprir ordens flagrantemente ilegais a tal Portaria o é, pois não? Queria ver uma Portaria do Ministério da Justiça dizendo que furtos quetais não deveriam ser perseguidos... Todos diriam: céus, que inconstitucionalidade. Pois é!

É induvidoso que o sistema penal-tributário, como hoje está posto, é flagrantemente contrário ao Princípio da Intervenção Mínima, pois este exige que somente as infrações que atentem gravemente contra os interesses do erário devam ser elevadas à categoria de ilícitos criminais. Dessa forma, o Direito Penal Tributário viola o Princípio da Proporcionalidade, uma vez que a proteção conferida por ele é insuficiente para o bem jurídico, pois a afronta estará perdoada com o pagamento integral do débito.

Convém lembrar que, os delitos contra a Ordem Tributária fazem parte dos chamados "crimes do colarinho branco", denominação criada pelo sociólogo Edwin Sutherland, quem também difundiu a Teoria da Associação Diferencial (ou Aprendizado da Delinquência). Para essa teoria, o comportamento criminoso é passível de aprendizagem, através de mecanismos ensinados por outros criminosos (HOFFMAN E FONTES, 2018, p. 143).

Ferro (2008, p. 7) assim analisa esta teoria:

Contudo, a teoria da associação diferencial de Sutherland não se concentra unicamente nas associações que determinam a criminalidade das classes baixas. Foi o autor quem introduziu o termo white-collar crime (crime de colarinho branco) no mundo acadêmico - em discurso intitulado The white collar criminal, proferido à American Sociological Society (Sociedade Americana de Sociologia), como seu presidente, em 1939 -, que seria pouco a pouco 


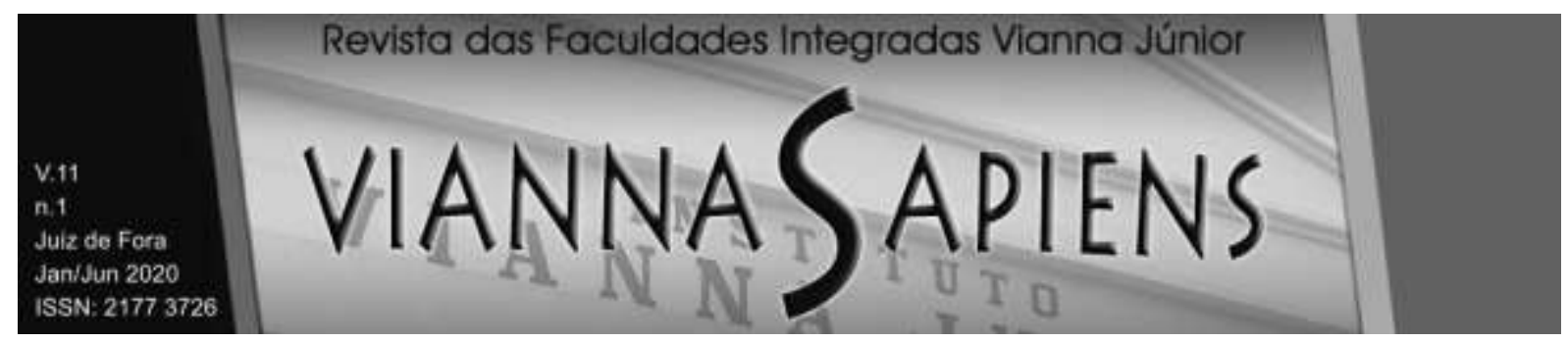

incorporado à linguagem científica nos Estados Unidos e em vários outros países, a exemplo da França (crime en col blanc), da Itália (criminalità in coletti bianchi) e da Alemanha (WeisseKragenKriminalität). O seu ensaio sobre o crime de colarinho branco, no universo da Criminologia, publicado em 1949, foi a sensação editorial daquela década.

Desse modo, o pagamento integral do débito tributário trará a extinção da punibilidade, evidenciando que o Direito Penal está sendo utilizado apenas como meio coercitivo para o pagamento de tributos. Através da ameaça de prisão, pagase a dívida tributária junto ao Fisco, não importando se o agente tinha o dolo de praticar o crime.

Nesse sentido, há a violação do Princípio da Proporcionalidade, sobretudo há proteção deficiente (Üntermassverbot), gerando impunidade.

\section{O TRATAMENTO DIFERENCIADO NA PUNIÇÃO DE CRIMES CONTRA A ORDEM TRIBUTÁRIA E DE CRIMES PATRIMONIAIS}

Como regra geral, o Direito Penal prevê, como consequência da reparação do dano, apenas o arrependimento posterior (art. 16 do Código Penal), consistindo em causa especial de diminuição de pena. Tal diminuição incide somente nos crimes cometidos sem violência ou grave ameaça à pessoa, e com a reparação do dano, ou restituída a coisa, até o recebimento da denúncia ou da queixa, por ato voluntário do agente. Por sua vez, a atenuante genérica prevista no art. 65, III, b, do Código Penal incide nos crimes contra o patrimônio se a reparação do dano ocorrer de forma posterior ao recebimento da denúncia.

Todavia, nos crimes tributários, a reparação integral do dano produz consequência distinta: a extinção da punibilidade. É verdade que há tratamento diferenciado nos crimes tributários em relação aos outros crimes, sobretudo os que atingem o patrimônio de particulares ou até mesmo o patrimônio público. Esse tratamento diferenciado é assim explicado por Ferro (2008, p. 18): 


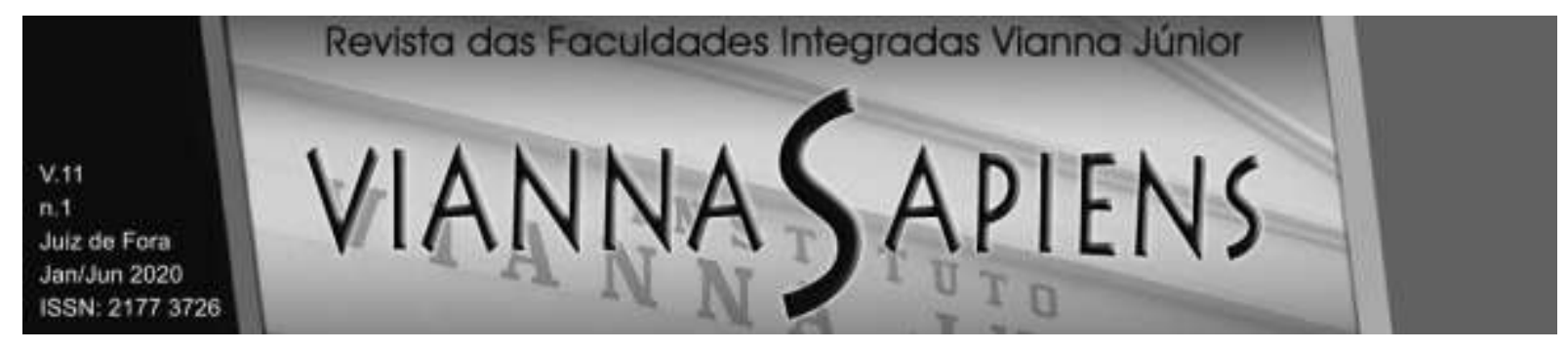

Outra estratégia dos homens de negócios em prol da salvaguarda de suas reputações é o seu esforço no sentido de uma implementação diferente das leis a eles aplicáveis, mediante substituições dos procedimentos cabíveis por outros menos estigmatizantes, posto que não desejam ser presos por policiais, nem ser forçados ao comparecimento perante uma corte penal, ou tampouco ser condenados pelo cometimento de delitos.

Nos delitos tributários, é certo que o dano social é maior que nos crimes patrimoniais, pois o bem juridicamente protegido pertence a todos/coletividade (erário, arrecadação tributária ou a própria ordem tributária), e não apenas a um indivíduo (HANGER JÚNIOR, 2015).

Há falta de isonomia entre o tratamento dispensado aos delitos contra o patrimônio (os previstos no título II do Código Penal) e aos crimes tributários (arts. 1ำ e $2^{\circ}$ da Lei n. 8.137/1990 e arts. 168-A, $\S 1^{\circ}$, I, e 337-A, ambos do CP). Extinguir a punibilidade pelo pagamento do tributo sonegado é injusto, pois tal benesse não é dada em crimes contra o patrimônio, a exemplo do furto (art. 155 CP). Assim, aquele que comete um crime menos grave não é favorecido pela extinção da punibilidade, mas somente com uma redução da pena.

O benefício concedido à criminalidade de colarinho-branco traduz a impunidade dos mais favorecidos economicamente, ainda que seus crimes causem maior impacto à sociedade. Assevera Streck (2015) que:

De todo modo, talvez isso seja assim porque nenhum de nós, do andar de cima, tem amigos ladrões. No máximo, temos amigos sonegadores e lavadores, disfarçados no meio das festas que frequentamos. Questão de classe social (ou de estamentos, diria Faoro). Ninguém diz: "- Ah, meu amigo foi processado por ter furtado um botijão de gás". Isso é para a gente que não usa botas. Nós, que usamos cano longo (Sete Léguas), estamos imunes a isso. Mas há várias situações do tipo: “- Ah, um amigo acaba de receber habeas corpus porque sonegou tributos, mas ficou ao abrigo de uma Portaria do Ministério da Fazenda". Bingo!

O Estado, ao dispensar parcela da arrecadação tributária (quando não ajuiza execuções fiscais para determinadas dívidas), diminui sua receita, acarretando perda 


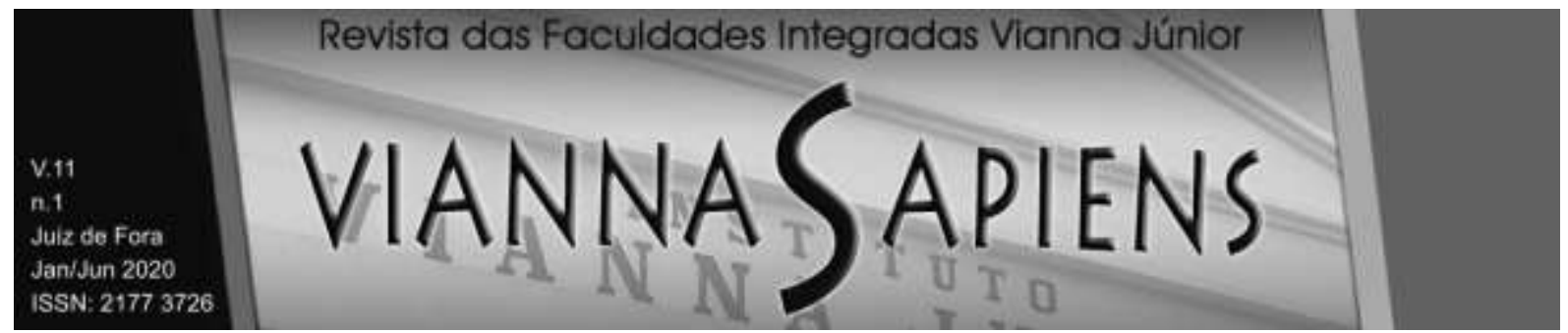

para os investimentos sociais, como educação, cultura, segurança pública, assistência social, gerando aumento de marginalização social e criminalidade. Enquanto isso, os homens "de colarinho branco" permanecem intocados pela justiça penal, sem privações, pois possuem todo o acesso a serviços que o dinheiro pode comprar. A mesma observação pode ser lida em Ferro (2008, p. 17):

Os homens de negócios, leciona o doutrinador, não se vêem como enquadrados no estereótipo do criminoso ainda quando violam a lei. Por outro lado, usualmente pensam em si mesmos como violadores da lei - um eufemismo, sem dúvida -, contudo o fazem com orgulho, jactando-se, em suas relações particulares, pela prática de tais violações, porque a lei e não a sua infringência é que lhes parece reprovável. São apoiados por seus colegas nas violações em causa, o que lhes assegura uma consciência que geralmente não Ihes incomoda. O sentimento de vergonha pelas práticas de negócios desleais, quando existente, parece reservado, com maior freqüência, aos homens de negócios mais jovens, por não haverem assimilado ainda, completamente, a mentalidade e as atitudes peculiares ao reino dos negócios.

Com efeito, é de difícil compreensão os motivos pelos quais se aplica o Princípio da Insignificância aos delitos de sonegação fiscal (arts. $1^{\circ}$ e $2^{\circ}$ da Lei $n$. 8.137/1990 e arts. 168-A, $\S 1^{\circ}$, I, e 337-A, ambos do CP), e não se aplica igual tratamento no caso de delitos contra o patrimônio. Entretanto, protege-se o criminoso de colarinho branco. Para a constatação dessa afirmação, basta analisar o tratamento jurídico dispensado ao arrependimento posterior e à extinção da punibilidade nos crimes contra a ordem tributária, bem como a atual posição da nossa Corte Suprema no tocante à aplicação do princípio da insignificância ao crime de descaminho $(R \$ 10.000,00)$ e ao furto de pequeno valor $(R \$ 100,00)$. Vejamos os julgados que demonstram a incoerência acima mencionada:

AGRAVO REGIMENTAL NO AGRAVO EM RECURSO ESPECIAL. FURTO DE R\$ 2,95 (DOIS REAIS E NOVENTA E CINCO CENTAVOS) EM MOEDAS. RESTITUIÇÃO A EMPRESA VÍTIMA. ESCALADA E ROMPIMENTO DE OBSTÁCULO. APLICAÇÃO DO PRINCÍPIO DA INSIGNIFICÂNCIA. CASO CONCRETO. ATIPICIDADE MATERIAL. AUSÊNCIA DE PERICULOSIDADE 


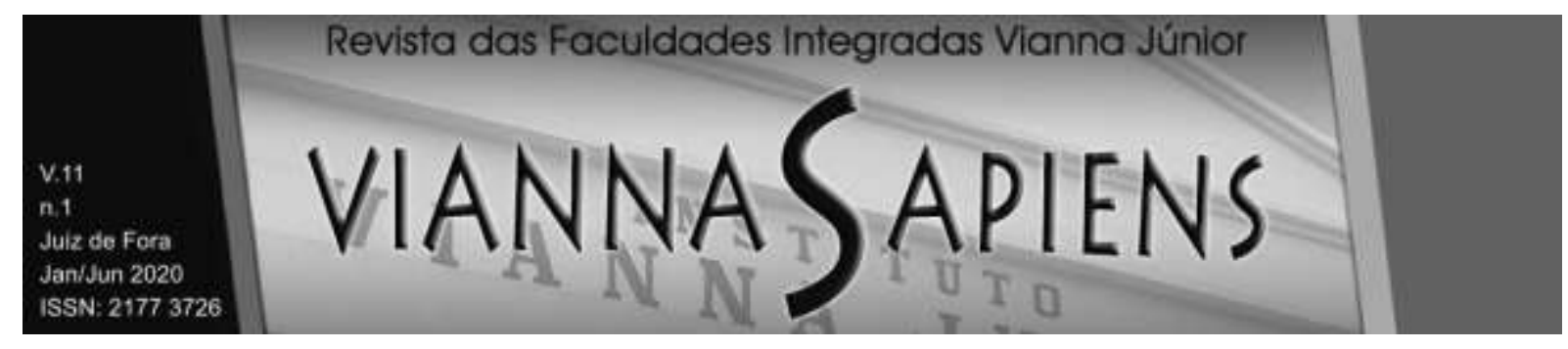

SIGNIFICATIVA DA CONDUTA DO AGENTE. EXCEPCIONALIDADE. AGRAVO REGIMENTAL DESPROVIDO.

1. De acordo com a orientação traçada pelo Supremo Tribunal Federal, a aplicação do princípio da insignificância demanda a verificação da presença concomitante dos seguintes vetores (a) a mínima ofensividade da conduta do agente, (b) a nenhuma periculosidade social da ação, (c) o reduzidíssimo grau de reprovabilidade do comportamento e (d) a inexpressividade da lesão jurídica provocada.

2. Como regra, a aplicação do princípio da insignificância tem sido rechaçada nas hipóteses de furto qualificado, tendo em vista que tal circunstância denota, em tese, maior ofensividade e reprovabilidade da conduta. Deve-se, todavia, considerar as circunstâncias peculiares de cada caso concreto, de maneira a verificar se, diante do quadro completo do delito, a conduta do agente representa maior reprovabilidade a desautorizar a aplicação do princípio da insignificância.

3. Ademais, embora seja pacífico na jurisprudência que a restituição

do produto do crime não constitui, por si só, motivo autorizador da aplicação do princípio da insignificância, indubitavelmente tal restituição, somada a outros fatores pode e deve ser considerada dentro do quadro definidor da reprovabilidade da conduta do(s) agente(s).

4. Acusado que, mediante escalada e rompimento de obstáculo, subtraiu $R \$ 2,95$ (dois reais e noventa e cinco centavos) em moedas, posteriormente restituído a empresavítima.

5. O Tribunal a quo, ao apreciar apelação, reduziu a pena-base ao mínimo legal e afastou a agravante da reincidência. Ainda que assim não fosse, esta Eg. Corte tem reconhecido a possibilidade de aplicação do princípio da insignificância a acusado reincidente que praticou furto qualificado.

6. Agravo regimental desprovido.

(AgRg no AREsp 785.755/MT, Rel. Ministro REYNALDO SOARES DA FONSECA, QUINTA TURMA, julgado em 22/11/2016, DJe 05/12/2016)

PENAL. PROCESSUAL PENAL E PROCESSUAL CIVIL. AGRAVO REGIMENTAL NO AGRAVO EM RECURSO ESPECIAL. FURTO QUALIFICADO. ROMPIMENTO DE OBSTÁCULO. PRINCÍPIO DA INSIGNIFICÂNCIA. IMPOSSIBILIDADE. ELEVADO GRAU DE REPROVABILIDADE DA CONDUTA. AGRAVO REGIMENTAL NÃO PROVIDO.

1. A jurisprudência do Superior Tribunal de Justiça é firme em assinalar que o rompimento de obstáculo para a prática do crime de furto denota a maior reprovabilidade da conduta dos agentes e afasta, por conseguinte, a incidência do princípio da insignificância. 


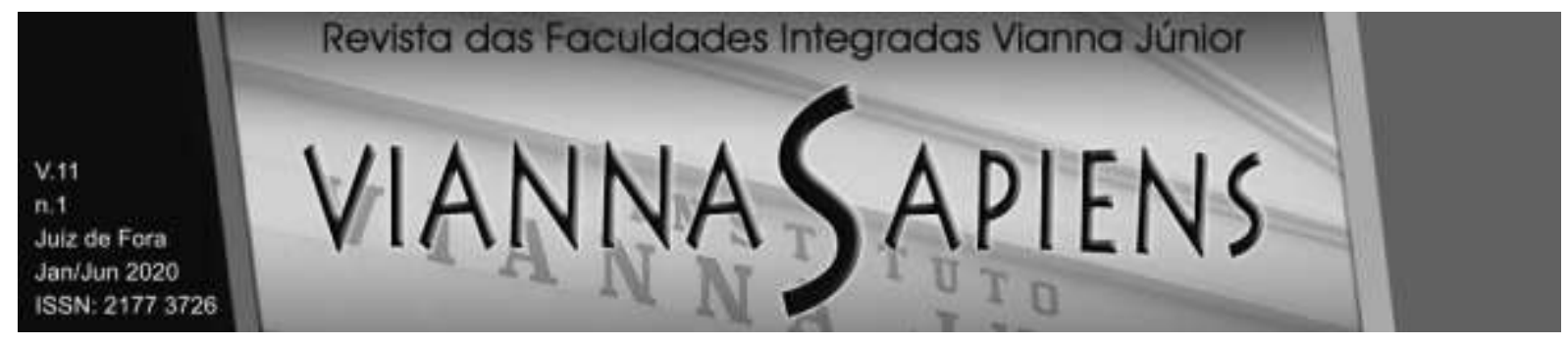

2. O Tribunal regional, ao apreciar o recurso defensivo, decidiu em consonância com o entendimento desta Corte. Incidência da Súmula

n. 83 do STJ.

3. Agravo regimental não provido.

(AgRg no AREsp 746.011/MT, Rel. Ministro ROGERIO SCHIETTI CRUZ, SEXTA TURMA, julgado em 05/11/2015, DJe 23/11/2015)

O fato é que, tendo em vista os objetivos do Direito Penal Tributário, bem como os bens jurídicos tutelados, não se justifica o tratamento mais benéfico dispensado aos que praticam crimes contra a ordem tributária. Nesse sentido é a opinião de Streck (2015):

Não que eu quisesse que se arrebentasse com os sonegadores. $O$ que eu queria era que fosse apenas aplicada a isonomia e a equanimidade. Por que o agente que pratica furto tem tratamento mais gravoso que o que sonega tributos?

Por medida de aplicação do Princípio da Isonomia, deve ser igual o tratamento dado aos criminosos comuns, que cometem crimes patrimoniais, e aos criminosos tributários, (arts. 16 ou 65, II, b, do CP), beneficiando-os apenas com a diminuição da sanção. Com efeito, há outra maneira para fazer valer o Princípio da Isonomia, que seria exatamente estender aos criminosos patrimoniais o mesmo tratamento dado aos que cometem delitos tributários, que é a extinção da punibilidade em razão da reparação do dano, visto que não há razão para beneficiar somente os criminosos tributários.

É importante refletir que a ordem tributária tem importância constitucional, e os direitos sociais são garantidos e custeados pelos tributos, de forma que um bem jurídico de tanta relevância requer suficiente proteção do Direito Penal. E se os delitos contra a ordem tributária são mais graves que os delitos patrimoniais sem violências, que sejam a estes estendidos iguais benefícios dados àqueles. 


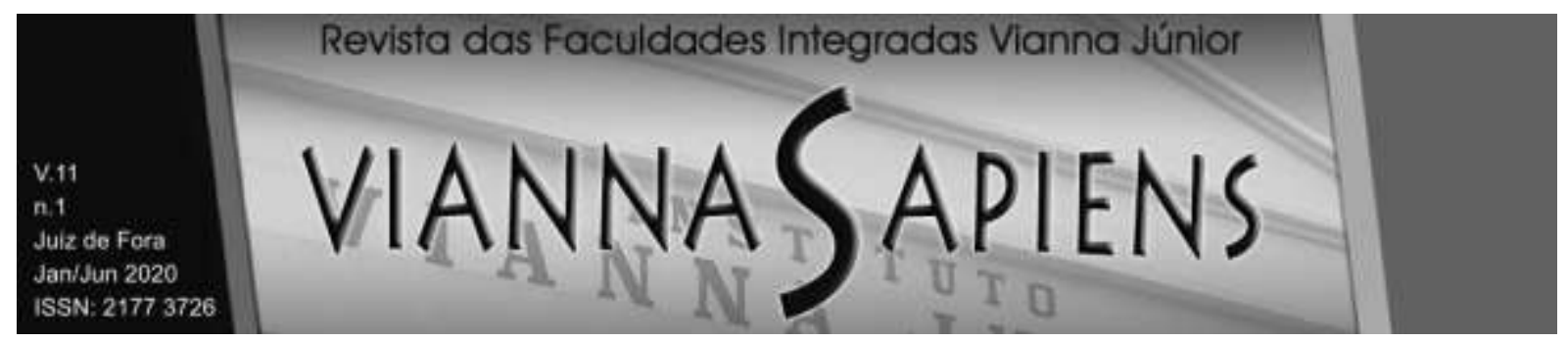

\section{CONCLUSÃO}

Nos crimes contra a Ordem Tributária, o pagamento integral do tributo gera a extinção da punibilidade, Assim, existe a possibilidade de qualquer pessoa, que tenha a intenção de cometer um crime tributário, ponderar a relação custo-benefício de sua ação. A lei penal-tributária não tutela de forma satisfatória a Ordem Tributária, a proteção é extremamente deficiente ao bem jurídico. Prova disso é a incapacidade da norma de causar temor aos sonegadores, claramente aqueles possuidores de poder econômico. O criminoso tributário não se sente criminoso, porque pode escolher ser apenado ou não.

Com efeito, é discrepante o tratamento dado aos criminosos tributários em relação aos que cometem crimes contra o patrimônio, o que gera violação ao Princípio da Isonomia, pois as reduções de pena aplicadas aos criminosos comuns são manifestamente mais desfavoráveis. Sabemos que o Direito Penal possui como objeto a proteção dos bens jurídicos considerados mais caros e importantes para a sociedade, e não deve ser utilizado como meio de arrecadação de tributos, sob pena de total deturpação de suas finalidades.

Conclui-se, assim, que o uso incorreto do Direito Penal Tributário, como simples instrumento de cobrança de dívidas fiscais, evidencia uma total proteção deficiente (üntermassverbot) do Estado, também violando o Princípio da Proporcionalidade.

\section{REFERÊNCIAS}

BALTAZAR JUNIOR, José Paulo. Crimes Federais. 11. ed. São Paulo: Saraiva, 2017. 


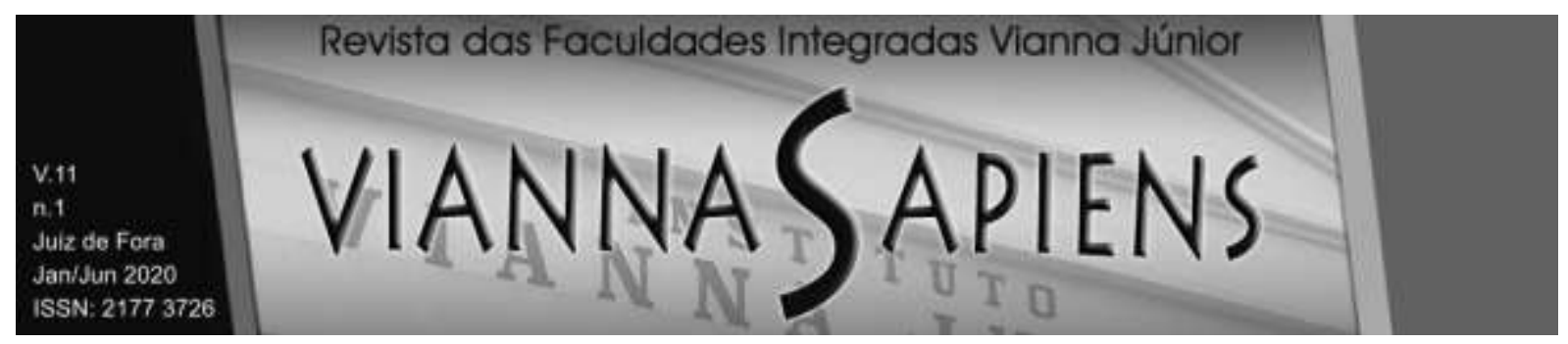

BARATTA, Alessandro. Criminologia Crítica e Crítica do Direito Penal: introdução à sociologia do direito penal. 6.ed. Tradução: Juarez Cirino dos Santos. Rio de Janeiro: Editora Revan: Instituto Carioca de Criminologia, 2017.

BITENCOURT, César Roberto. Tratado de Direito Penal, parte geral, arts 1ำ ao 120. 24. ed. São Paulo, Saraiva: 2018.

BUSATO, Paulo César. Direito Penal, parte geral. 2. ed. São Paulo: Editora Atlas, 2015.

CAMPOS, Hélio Silvio Ourém; FREIRE, Sheyla Canuto Barbosa. Extinção da punibilidade pelo pagamento integral do débito tributário em decisão do stf: ineficácia do direito penal tributário. In: Revista Eletrônica do Curso de Direito da UFSM, v. 12, n. 3 / 2017.

CAPEZ, Fernando. Curso de Direito Penal, parte geral. 15. ed. São Paulo: Saraiva, 2011.

CUNHA, Rogério Sanches. Manual de direito penal: parte geral. 4 . ed.Salvador: Juspodivm, 2016.

DIAS, Jean. A proibição do excesso (Übermassverbot) e a proibição de proteção deficiente (Untermassverbot) no direito penal. Disponível em:

$<$ https://jeancarlodias.jusbrasil.com.br/artigos/429256367/a-proibicao-doexcesso- ubermassverbot-e-a-proibicao-de-protecao-deficienteuntermassverbot-no-direito-penal>. Acessado em 07 de maio de 2020.

FERRO, Ana Luísa Almeida. Sutherland: a teoria da associação diferencial e o crime de colarinho branco. In: De Jure - Revista Jurídica do Ministério Público de Minas Gerais. Ministério Público do Estado de Minas Gerais. n. 11 (jul./dez. 2008). Belo Horizonte: Ministério Público do Estado de Minas Gerais.

GRECO, Rogério. Curso de Direito Penal, Parte Geral. 17 ed. Rio de Janeiro: Impetus, 2015. 


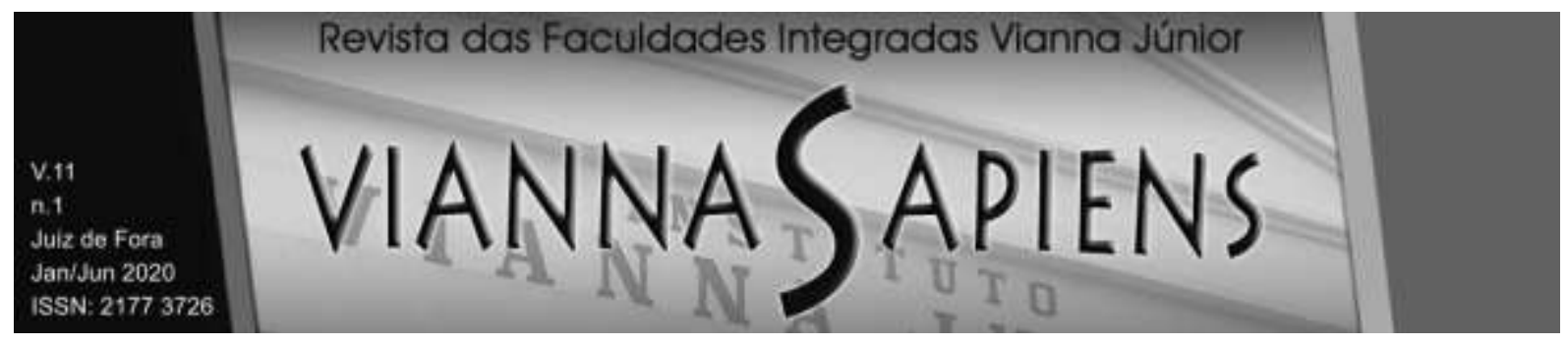

HANGER JUNIOR, João Carlos. A insignificância como sintoma da crise dogmática do direito penal e sua autonomia nos crimes tributários. In: Revista Brasileira de Ciências Criminais. v. 23, n. 117. Nov - Dez, 2015.

HOFFMANN, Henrique; FONTES, Eduardo. Criminologia. 2. ed. Salvador: Juspodvm, 2018.

LOVATTO, Alecio Adão. Crimes tributários: aspectos criminais e processuais. Porto Alegre: Livraria do Advogado, 2000.

MANSOLDO, Mary Cristina Neves. Crimes tributários sob a ótica da criminologia crítica: extinção da punibilidade pelo pagamento do tributo e a teoria do etiquetamento. In: Revista Quesatio luris, v. 11, n.02, Rio de Janeiro, 2018.

MASSON, Kleber. Direito Penal Esquematizado: parte geral. 13 ed. v. 1. São Paulo: Método, 2019.

PAULSEN, Leandro. Curso de Direito Tributário Completo. 8.ed. São Paulo, Saraiva: 2017.

PINTO, Emerson de Lima. A criminalidade econômico-tributária: a (des)ordem da lei e a lei da (des)ordem. Porto Alegre: Livraria do Advogado, 2001.

QUEIROZ, Paulo. Direito Penal: parte geral. 3 ed. São Paulo: Saraiva, 2006.

SARLET, Ingo Wolfgang. Dignidade (da pessoa) Humana e Direitos

Fundamentais na Constituição Federal de 1988. 10. ed. Porto Alegre: Livraria do Advogado editora, 2015.

SOUSA, Susana Aires de. Os crimes fiscais: análise dogmática e reflexão sobre a legitimidade do discurso criminalizador. Coimbra: Coimbra Editora, 2006. 


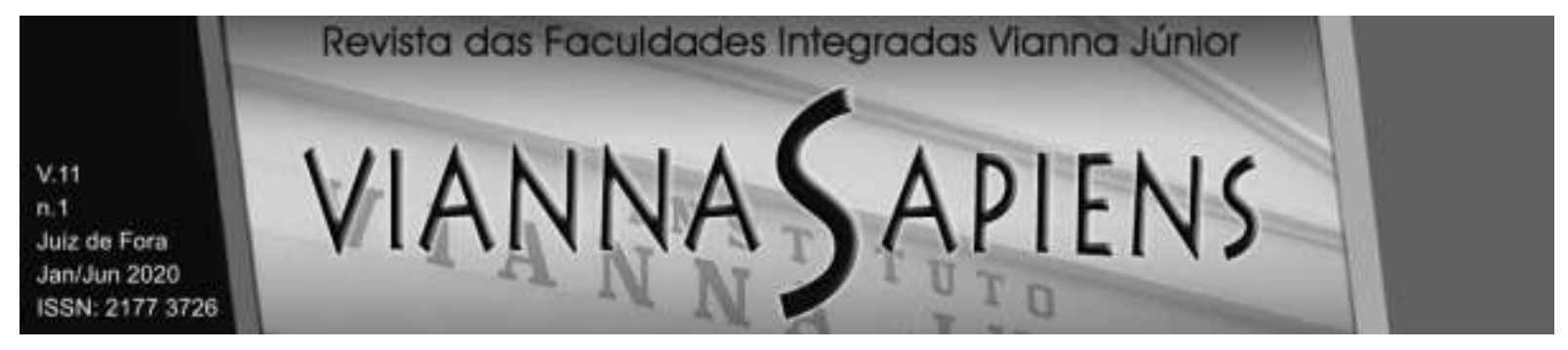

STRECK, Lênio. Em Pindorama, furtar R\$ 100 é mais grave que sonegar $\mathbf{R}$ \$9.999! Disponível em: <https://www.conjur.com.br/2015-jan-29/sensoincomum-pindorama-furtar-100-grave-sonegar-19999>. Acessado em: 07 de maio de 2020.

Hermenêutica Jurídica $\mathrm{e}(\mathrm{m})$ Crise: Uma exploração hermenêutica da construção do Direito. In: O Estado Democrático de Direito:

procedimentalismo versus substancialismo e os obstáculos representados pelo paradigma do modo (modelo) de produção do Direito e do paradigma epistemológico da filosofia da consciência. 4.ed. Porto Alegre: Livraria do Advogado, 2003.

Recebido em 24/04/2020

Publicado em 12/05/2020 